\title{
Kematangan Karier Siswa: Peranan Tipe Kepribadian dan Dukungan Sosial
}

\section{Student's Career Maturity: The Role of Personality Type and Social Support}

\author{
Mida Tahmidiyatul Milah ${ }^{1}$, Deden Sudirman ${ }^{1}$,F.Fridayanti1 ${ }^{*}$ \\ ${ }^{1}$ Fakultas Psikologi, Universitas Islam Negeri Sunan Gunung Djati \\ *fridayanti@uinsgd.ac.id
}

\begin{abstract}
Abstrak
Kematangan karier merupakan kesiapan individu dalam menentukan karier yang tepat di masa mendatang sesuai dengan pengetahuan yang diperlukan untuk membuat pilihan karier yang realistis. Penelitian ini dilakukan dengan tujuan untuk mengetahui peranan atau pengaruh faktor kepribadian dan dukungan sosial terhadap kematangan karier siswa. Metode penelitian yang digunakan adalah pendekatan kuantitatif dengan analisis kausalitas. Responden penelitian ini sebanyak 205 partisipan (perempuan 164 orang dan laki-laki 41orang; dengan rentang usia 17-19 tahun mean $=17 \mathrm{sd}=0.54$ ). Teknik pengumpulan data menggunakan kuesioner big five personality (BFI, Pervin, \& John, 1999), dukungan sosial (social provisions scale, Cutrona, C. E., Russell, D. W. 1987), dan kematangan karier (CMI-Form C, Savickas 2011). Analisis data dalam penelitian ini menggunakan analisis regresi linier berganda. Hasil penelitian menunjukan bahwa dukungan sosial berkontribusi secara signifikan terhadap kematangan karir baik secara simultan atau terpisah. Adapun dalam hal factor kepribadian, meski secara Bersama-sama factor kepribadian dan dukungan sosial berpengaruh terhadap kematangan karir, namun bila ditelisik lebih jauh diperoleh hasil bahwa faktor kepribadian concientiounesslah yang memiliki peran signifikan terhadap kematangan karir, Adapun faktor-faktor kepribadian lainnya tidak berpengaruh secara signifikan.
\end{abstract}

Kata kunci : kematangan karier, big-five personality; dukungan sosial

\begin{abstract}
Career maturity is an individual's readiness to determine the right career in the future according to the knowledge needed to make realistic career choices. This research was conducted with the aim of knowing the role or influence of personality factors and social support on students' career maturity. The research method used is a quantitative approach with causality analysis. Respondents in this study were 205 participants (164 women and 41 men; with an age range of 17-19 years, mean $=17$ to $=0.54$ ). Data collection techniques used the big five personality questionnaire (BFI, Pervin, \& John, 1999), social support (social provisions scale, Cutrona, C. E., Russell, D. W. 1987), and career maturity (CMI-Form C, Savickas 2011). Data analysis in this study used multiple linear regression analysis. The results showed that social support contributed significantly to career maturity either simultaneously or partially. In terms of personality factors, although together the personality factor and social support affect career maturity. when examined further, the results showed that the only concientiouness that have a significant role in career maturity. Mean while, other personaliy factors had no significant effect.
\end{abstract}

Keywords: career maturity, big five personality; social support

\section{Pendahuluan}

Karier didefinisikan sebagai kombinasi dan urutan peran yang dimainkan oleh seseorang selama seumur hidup (Super, 1980). Kemudian, dalam (Ratnaningsih et al., 2016) Karier merupakan suatu ancaman utama bagi kehidupan seseorang, hal ini termasuk membuat proses pengambilan keputusan 
seumur hidup. Salah satu tugas perkembangan terpenting remaja adalah mempersiapkan karier (Ratnaningsih et al., 2016).Masa remaja merupakan suatu masa yang rentang di dalam kehidupan, masa dimana individu mulai mendapatkan masalah, mencari identitas diri, usia yang dianggap menyeramkan, dan masa diambang menuju kedewasaan (Herlina, 2013). Sejak awal masa remaja, indvidu dihadapkan pada pilihan dan persiapan diri untuk terlibat dalam suatu pekerjaan atau karier yang dapat menentukan individu dalam menghadapi berbagai hal kehidupan (Saifuddin et al., 2017).

Kematangan karier adalah kemampuan seseorang dalam menentukan pilihan karier yang sesuai, seperti mengetahui kondisi yang diperlukan dalam membuat keputusan karier dan sejauh mana pilihan tersebut sesuai dan konsisten selama periode waktu tertentu (Levinson et al., 1998). Kematangan karier juga dapat diartikan sebagai sejauh mana seseorang memiliki pengetahuan dan keterampilan yang diperlukan untuk membuat pilihan karier yang bijaksana dan tepat. Super (Savickas, 2001) menjelaskan bahwa jika seseorang memiliki pengetahuan yang matang atau kemampuan untuk membuat keputusan karier dan memiliki pengetahuan tentang keputusan karier berdasarkan pekerjaan, maka karier tersebut didasarkan pada eksplorasi yang telah dilakukan dengan menunjukan sikap perencanaan terhadap masa depan.Hal ini yang harus dipersiapkan oleh individu mencari informasi, membuat keputusan karier yang sesuai dengan usia dan mengatasi tugas pengembangan karier yang tepat (Levinson et al., 1998).

Pada Sebagian remaja siswa sekolah menengah, kematangan karir tidak terbentuk sepenuhnya. kematangan karir yang rendah ditandai dengan beberapa kriteria seperti kurangnya perencanaan karir, kurangnya melakukan eksplorasi karier, kurang memadai pengetahuan terkait pengambilan keputusan karier, kurang memiliki pengetahuan yang luas tentang dunia kerja, kurang memadainya pengetahuan terkait kelompok pekerjaan yang lebih disukai sesuai kemampuan yang dimiliki(Savickas, 2001). Remaja menjadi kurang memiliki kematangan karier disebabkan karena beberapa hal seperti kurangnya kesadaran atau kepedulian tentang pilihan yang akan segera mereka hadapi. Kondisi ini membuat siswa-siswi sekolah menengah kurang atau memiliki kematangan karier yang rendah dan menimbulkan kebingungan setelah lulus ataupun dalam menyelesaikan pendidikan formalnya

Beberapa penelitian mengenai kematangan karier menunjukan bahwa terdapat hubungan positif antara efikasi diri terhadap kematangan karir siswa(Iman Setiyanto, 2014). Penelitian lain menemukan bahwa terdapat hubungan positif yang signifikan antara kelekatan terhadap teman sebaya dengan kematangan karir (Muntamah, Jati Ariati, 2016)

Kematangan karier dipengaruhi oleh faktor internal dan eksternal. Faktor internal kematangan karier ialah trait kepribadian. kepribadian merupakan faktor penentu bagaimana seseorang akan berperilaku di berbagai situasi. Kepribadian dapat mempengaruhi keputusan karier seseorang, prestasi kerja, pilihan karier, dan kepuasan (Atli, 2017).

Kepribadian dapat dikenali diataranya menggunakan model sifat (trait) kepribadian lima factor atau big five personality. Big Five Personality merupakan suatu pendekatan yang digunakan dalam ilmu psikologi untuk melihat kepribadian manusia melalui sifat yang tersusun kedalam lima buah domain kepribadian yang telah dibentuk dengan menggunakan analisis faktor. Big Five Personality tersebut meliputi openness to experience, conscientiousness, extraversion, agreeableness, dan neuroticism. Model ini dikemukakan oleh Costa \& McCrae, dan mereka menemukan bahwa big five Personality dapat menjelaskan dan memprediksi perilaku dengan baik. Penelitian terdahulu mengenai sifat kepribadian sebagai predictor bagi maturitas karir menemukan bahwa siswa menengah menunjukkan hasil yang signifikan $\left(\mathrm{R}=.35, \mathrm{R}^{2}=.12, \mathrm{p}<.05\right)$ dengan kontribusi tertinggi adalah Neuroticism $(B=-.158)$, diikuti oleh Extraversion $(B=.148)$, Openness to experience $(B=.109)$, Agreeableness $(B=.090)$, Conscientiousness $(B=.083)$. temuan penelitian ini menunjukan bahwa sifat kepribadian lima faktor big five personality dapat menjadi predictor bagi kematangan karir Atli Abdullah, (2017)

Kematangan karir juga dapat dipengaruhi oleh factor eksternal berupa dukungan sosial yang dapat diperoleh dari lingkungan sekitar, keluarga, teman terdekat, bahkan dari pasangan. Weiss (dalam Cutrona, Russell, \& Rose, 1986) menyatakan bahwa dukungan sosial adalah hubungan antar individu yang memiliki persepsi bahwa seseorang merasa dicintai, disayangi, dihargai untuk memberikan bantuan kepada individu yang mengalami tekanan-tekanan dalam hidupnya. penelitiannya menunjukkan bahwa terdapat hubungan positif dan signifikan antara dukungan sosial dan kematangan karir pada siswa dengan sumbangan relatif dukungan sosial terhadap kematangan karir sebanyak $22 \%$, Listyowati et al., (2012) Penelitian lain juga Dukungan sosial teman sebaya berpengaruh positif 
terhadap kematangan karier pada mahasiswa perantau (dengan dukungan sosial teman sebaya memberikan sumbangan positif sebesar $36,1 \%$ Pramanasari Sintya (2019). Temuan ini mendukung adanya peranan dukungan sosial terhadap kematangan karir siswa

Atas dasar bahwa factor kepribadian dan dukungan sosial memiliki peranan terhadap kematangan karir, penelitian ini ingin menguji apakah sifat kepribadian dan dukungan sosial secara Bersama-sama maupun secara parsial berperan terhadap kematangan karir siswa.

\section{Metode Penelitian}

Penelitian ini menggunakan metode penelitan kuantitatif dengan analisis kausalitas yang bertujuan untuk mengetahui ada tidaknya pengaruh antara variabel independen terhadap variabel dependen (Sugiyono, 2012). Populasi dalam penelitian ini adalah siswa SMKN 7 Bandung kelas XII usia 17-19 tahun, hal tersebut atas pertimbangan karena siswa kelas XII akan menghadapi pilihan karier selanjutnya sesuai dengan kemampuan dan jurusan dirinya selepas dari Sekolah Menengah Kejuruan. Teknik sampling yang digunakan pada penelitian ini adalah stratified random sampling, besarnya sample yang digunakan dalam penelitian ini adalah 205 siswa dengan taraf kesalahan 5\%. Jumlah sample tersebut didapat dari perhitungan rumus Isaac dan Michael.

Proses pengambilan data dilakukan melalui angket (kuesioner) dengan model skala likert. Skala Big Five Personality (BFI) dikembangkan oleh Pervin dan John (1999), alat ukur ini terdiri dari 44 item meliputi lima aspek yaitu Openness to experience (10 item), Conscientiousness (9 item), Extraversion (8item), Agreeableness (9 item), dan Neuroticism (8 item). Pilihan jawaban dalam alat ukur ini diberikan skor skala mulai dari 5-1 (sangat setuju), (setuju), (netral), (tidak setuju), dan (sangat tidak setuju) untuk item favourable sedangakan skor skala mulai dari 1-5 (sangat setuju), (setuju), (netral), (tidak setuju), dan (sangat tidak setuju) untuk item unfavorable. Semakin tinggi skor yang didapat maka semakin tinggi pula tingkat kepribadian yang dimiliki oleh siswa SMK. Hasil coba alat ukur menunjukan bahwa skala ukur big five personality reliabel yakni dengan nilai koefisien reliabilitas cronbach's alpha 0,765 .

Adapun variabel dukungan sosial menggunakan alat ukur Social Provisions Scale yang dikembangkan oleh Cutrona, C. E., Russell, D. W. (1986), alat ukur ini terdiri dari 24 item meliputi enam aspek yaitu attachment (4 item), social integration (4 item), reasurrance of worth (4 item), reliable alliance (4 item), guidance (4 item), dan opportunity for nurturance (4 item). Pilihan jawaban dalam alat ukur ini diberikan skor skala mulai dari 4-1 (sangat setuju), (setuju), (tidak setuju), dan (sangat tidak setuju) untuk item favourable sedangakan skor skala mulai dari 1-4 (sangat setuju), (setuju), (tidak setuju), dan (sangat tidak setuju) untuk item unfavorable. Semakin tinggi skor yang didapat maka semakin tinggi pula tingkat dukungan sosial yang dimiliki oleh siswa SMK. Hasil coba alat ukur menunjukan bahwa skala ukur dukungan sosial reliabel yakni dengan nilai koefisien reliabilitas cronbach's alpha 0,825 .

Sedangkan untuk skala kematangan karier menggunakan skala ukur Career Maturity Inventory-form $C$ yang dikembangkan oleh Savickas (2011), alat ukur ini terdiri dari 24 item meliputi empat aspek yaitu concern (6 item), coriusity (6 item), confidence (6 item), dan consultation (6 item). Pilihan jawaban dalam alat ukur ini diberikan skor skala mulai dari 2-1 (setuju) dan (tidak setuju) untuk item favourable sedangakan skor skala mulai dari 1-2 (setuju) dan (tidak setuju) untuk item unfavorable. Semakin tinggi skor yang didapat maka semakin tinggi pula tingkat kematangan karier yang dimiliki oleh siswa SMK. Hasil coba alat ukur menunjukan bahwa skala ukur kematangan karier reliabel yakni dengan nilai koefisien reliabilitas cronbach's alpha 0,661 .

Skala ukur big five personality, dukungan sosial dan kematangan karier diadaptasi oleh peneliti dengan melakukan penerjemahan oleh dua orang kemudian dilakukan expert judment oleh satu orang ahli psikologi. Teknik analisis yang digunakan dalam penelitian ini adalah regresi linier berganda menggunakan software program SPSS V24. 


\section{Hasil Penelitian}

Dalam penelitian ini diperoleh total responden penelitian sebanyak 205 responden. Rincian karakteristik demografi dari responden dapat dilihat pada tabel 2.

Tabel 2 Karakteristik responden

\begin{tabular}{lcccc}
\hline Karakteristik responden & Frekuensi & Presentase & Mean & SD \\
\hline Laki-laki & 41 & $20 \%$ & & \\
Perempuan & 164 & $80 \%$ & & \\
Usia: & & & 17 & 0,54 \\
\multicolumn{1}{l}{17} & 123 & $60 \%$ & & \\
\multicolumn{1}{l}{18} & 77 & $37,60 \%$ & &
\end{tabular}

Perencanaan setelah lulus sekolah :

Bekerja $130 \quad 63,40 \%$

Melanjutkan pendidikan

$75 \quad 36,60 \%$

Berdasarkan tabel 2, diketahui bahwa rata-rata usia responden adalah 17 tahun (SD= 0.54). Karakteristik responden dilihat dari jenis kelamin perempuan $80 \%$ dan laki-laki 20\%. Kemudian perencanaan setelah lulus sekolah sebanyak $63,4 \%$ memilih bekerja dan sebanyak $36,6 \%$ memilih melanjutkan pendidikan.

\section{Hasil Uji Asumsi Klasik.}

Sebelum dilakukan pengujian hipotesis dengan analisis regresi linier berganda, diperlukan serangkaian uji asumsi klasik terlebih dahulu guna untuk memenuhi persyaratan dalam menggunakan analisis regresi. Pada penelitian ini beberapa pengujian yang dilakukan dalam asumsi klasik yaitu uji normalitas, lineritas, multikolinieritas, dan heteroskedastisitas.

\section{Uji Normalitas}

Pengujian normalitas dilakukan menggunakan metode kolmogorov-smirnov dengan taraf signifikansi $>0,05$. Hasil uji dapat dilihat pada tabel 3. Berdasarkan uji pada tabel 3 didapatkan nilai kolmogorov-smirnov sebesar 0,074 (Asymp.Sig. > 0,05), artinya data pada variabel-variabel penelitian ini berdistribusi secara normal.

Tabel 3 Hasil Uji Normalitas

\begin{tabular}{ccc}
\hline Kriteria & Sig. & Keterangan \\
\hline Unstandardized Residual & .074 & Normal \\
\hline
\end{tabular}

\section{Uji Linieritas}

Pengujian linearitas digunakan menggunakan analisis tabel ANOVA. Hasil uji dapat dilihat pada tabel 4. Berdasarkan uji pada tabel 4, pada variabel big five personality didapatkan nilai Deviation from linierity $(>0,05)$ sebesar 0,151 , artinya terdapat hubungan yang linear antara big five personality dengan kematangan karier. Selanjutnya pada variabel dukungan sosial didapatkan nilai Deviation from linierity $(>0,05)$ sebesar 0,956 , artinya terdapat hubungan yang linear antara dukungan sosial dengan kematangan karier

Tabel 4 Hasil Uji Linieritas

\begin{tabular}{|c|c|}
\hline Model & Sig. \\
\hline Tipe Big Five Personality & .151 \\
\hline Dukungan Sosial & .956 \\
\hline
\end{tabular}




\section{Uji Multikolinieritas}

Hasil uji multikolinieritas pada variabel big five personality dan dukungan sosial dapat dilihat pada tabel 5. Berdasarkan uji pada tabel 5 big five personality dan dukungan sosial memiliki nilai tolerance lebih dari 0,10 dan nilai VIF kurang dari 10, artinya dapat dikatakan bahwa tidak terdapat masalah multikolinearitas antar variabel independen.

Tabel 5 Hasil Uji Multikolinieritas

\begin{tabular}{lcc}
\hline \multicolumn{1}{c}{ Model } & Tolerance & Collinearity Statistics \\
& .846 & 1,182 \\
Tipe Big Five Personality & .846 & 1,182 \\
Dukungan Sosial & .86 & \\
\hline
\end{tabular}

\section{Uji Heteroskedastisitas}

Hasil uji heteroskedastisitas pada variabel big five personality dapat dilihat pada tabel 6 . Berdasarkan uji pada tabel 6, big five personality memiliki nilai signifikan 0,390 dan dukungan sosial memiliki nilai signifikan 0,280 tidak ada yang kurang dari 0,05 (Sig. > 0,05), artinya tidak terdapat gejala heteroskedastisitas pada model regresi dalam penelitian ini. Pengujian untuk mengetahui ada atau tidaknya gejala heteroskedastisitas dalam model regresi dengan kriteria nilai signifikan $>0,05$.

Tabel 6 Hasil Uji Heteroskedastisitas

\begin{tabular}{lc}
\hline \multicolumn{1}{c}{ Model } & Sig. (2-tailed) \\
\hline Tipe Big Five Personality & .390 \\
Dukungan Sosial & .280 \\
\hline
\end{tabular}

Berdasarkan pengujian asumsi klasik yang telah dilakukan tersebut, maka dapat disimpulkan bahwa data memenuhi persyaratan untuk dilakukan pengujian hipotesis dengan analisis regresi linier berganda.

\section{Hasil Uji Regresi Linier Berganda.}

\section{Hasil Uji F (uji simultan).}

Pengujian ini dilakukan untuk mengetahui pengaruh secara keseluruhan variabel independen terhadap variabel dependen. Hasil uji simultan (uji-F) dapat dilihat pada tabel 7 dan 8. Hasil uji simultan (Uji-F) ditunjukan pada tabel 7 menunjukan bahwa terdapat pengaruh yang signifikan antara kedua variabel big five personality dan dukungan sosial tehadap kematangan karier siswa [ F (6) = $5.899, \mathrm{p}=.000 \mathrm{R}^{2}=.152$ ]. koefisien determinasi pada tabel 8 menunjukan bahwa varians prediktor dapat menjelaskan $0.152(15.2 \%)$ dari varians variabel dependen sisanya sebesar 84,8\% dipengaruhi variabel lain yang tidak diteliti pada penelitian ini

Tabel 7 Hasil ANOVAa

\begin{tabular}{|c|c|c|c|c|c|c|}
\hline \multicolumn{2}{|c|}{ Model } & Sum of Squares & $\mathrm{df}$ & Mean Square & $\mathbf{F}$ & Sig. \\
\hline 1 & Regression & 305.547 & 6 & 50.924 & 5.899 & $.000^{\mathrm{b}}$ \\
\hline & Residual & 1709.205 & 198 & 8,632 & & \\
\hline & Total & 2014.751 & 204 & & & \\
\hline
\end{tabular}

a. Dependent Variable: Kematangan Karier

b. Predictors: (Constant), Dukungan Sosial, Neuroticism, Openness to experience, Agreeableness, Extraversion, Conscientiousness

Tabel 8 Model Summary 


\begin{tabular}{lccrrr}
\hline & & & \multicolumn{2}{c}{ Adjusted } & \multicolumn{2}{c}{ R } & \multicolumn{2}{c}{ Std. Error of the } \\
Model & $\mathbf{R}$ & R Square & & Square & \multicolumn{1}{c}{ Estimate } \\
\hline 1 &, $389^{\mathrm{a}}$ & &, 152 &, 126 & 2,938 \\
\hline
\end{tabular}

a. Predictors: (Constant), Dukungan Sosial, Neuroticism, Openness to experience, Agreeableness, Extraversion, Conscientiousness

\section{Model persamaan regresi.}

Model persamaan regresi adalah $: \hat{\mathrm{Y}}=16,714+0,164 \mathrm{X}_{1}+0,116 \mathrm{X}_{2}$

Persamaan regresi diatas memiliki arti sebagai berikut:

a. Nilai konstanta $(\alpha)=16,714$

Apabila variabel tipe kepribadian dan dukungan sosial diasumsikan tetap atau 0, maka kematangan karier siswa sebesar 16,714

b. Koefisien Big five personality $\left(\mathrm{X}_{1}\right)$ yang berpengaruh conscientiousness $=0,164$

Artinya jika siswa memiliki tipe kepribadian conscientiousness $\left(\mathrm{X}_{1}\right)$, maka tingkat kematangan karier akan naik sebesar 0,164 satuan.

c. Koefisien Dukungan Sosial $\left(\mathrm{X}_{2}\right)=0,116$

Artinya jika siswa mendapatkan dukungan sosial $\left(\mathrm{X}_{2}\right)$, maka tingkat kematangan karier akan naik sebesar 0,116 satuan.

\section{Hasil Uji Parsial (Uji-t)}

Berikutnya dilakukan Uji-t dilakukan untuk mengetahui pengaruh variabel prediktif secara parsial atau masing-masing terhadap variabel kriterion. Hasil uji-t dapat dilihat pada tabel 9. Berdasarkan uji parsial (uji-t) didapatkan hasil bahwa variabel big five personality $(\mathrm{B}=.120 \mathrm{p}=.094<0,05)$ dan dukungan sosial $(\mathrm{B}=.300 \mathrm{p}=.000<0,05)$ berpengaruh terhadap kematangan karier siswa

Tabel 9 Hasil Uji Parsial (Uji-t)

\begin{tabular}{|c|c|c|c|c|c|c|}
\hline \multicolumn{2}{|c|}{ Model } & \multicolumn{2}{|c|}{$\begin{array}{l}\text { Unstandardized } \\
\text { Coefficients }\end{array}$} & \multirow[t]{2}{*}{$\begin{array}{c}\text { Standardized } \\
\text { Coefficients }\end{array}$} & \multirow{2}{*}{$\frac{\mathbf{t}}{6,592}$} & \multirow{2}{*}{$\begin{array}{l}\text { Sig. } \\
, 000\end{array}$} \\
\hline 1 & (Constant) & 16,110 & 2,444 & & & \\
\hline & Big-Five Personality & ,036 &, 021 &, 120 & 1,680 & ,094 \\
\hline & Dukungan Sosial & 118 & ,028 & ,300 & 4,212 & ,000 \\
\hline
\end{tabular}

Karena tipe kepribadian merujuk pada dimensi yang berbeda, hasil uji masing-masing dimensi ditunjukkan pada tabel 10. Berdasarkan hasil uji pada tabel 10, diketahui bahwa hanya dimensi kepribadian conscintiousness yang menunjukan pengaruh signifikan $(B=0.185 \mathrm{p}=.032<0,05)$ terhadap kematangan karir. Adapun Dimensi kepribadian Openness to experience tidak menunjukkan pengaruh secara signifikan $(B=-.019, p=.796<0,05)$. dimensi extraversion tidak berkontribusi secara signifikan $(B$ $=-031, \mathrm{p}=.710<0,05)$. Dimensi agreeableness tidak berkontribusi secara signifikan $(B=-.017, \mathrm{p}=.844<$ $0,05)$, demikian pula dimensi neuroticism tidak berkontribusi secara signifikan $(B=-.022 \mathrm{p}=0,760<$ $0,05)$ terhadap kematangan karir. Apabila diurutkan berdasarkan nilai kontribusi, maka kontribusi tertinggi berasal dari Conscientiousness $(B=.185)$ Agreeableness $(B=.017)$, Openness to experience $(B=$ .019) Neuroticism $(B=-, 022)$, diikuti oleh Extraversion $(B=-, 031)$.

Tabel 10 Hasil Uji F Big Five Personality Secara Khusus 


\begin{tabular}{|c|c|c|c|c|c|c|}
\hline \multicolumn{2}{|c|}{ Model } & \multicolumn{2}{|c|}{$\begin{array}{l}\text { Unstandardized } \\
\text { Coefficients }\end{array}$} & \multirow[t]{2}{*}{$\begin{array}{c}\text { Standardized } \\
\text { Coefficients }\end{array}$} & \multirow{2}{*}{$\frac{\mathrm{t}}{5.428}$} & \multirow{2}{*}{$\begin{array}{l}\text { Sig. } \\
.000\end{array}$} \\
\hline 1 & (Constant) & 16.714 & 3.079 & & & \\
\hline & Openness to experience & -.016 & .061 & -.019 & -.258 & .796 \\
\hline & Conscientiousness &, 164 & .076 & .185 & 2.154 & .032 \\
\hline & Extraversion & -.021 & .058 &,- 031 & -.372 & .710 \\
\hline & Agreeableness & .019 & .097 & .017 & .197 & .844 \\
\hline & Neuroticism & -.057 & .186 &,- 022 &,- 306 & .760 \\
\hline & Dukungan Sosial & .116 & .028 & .294 & 4.090 & .000 \\
\hline
\end{tabular}

a. Dependent Variable: Career Maturity

\section{Pembahasan}

Hasil uji hipotesis Tipe kepribadian Big Five Personality dan Dukungan Sosial terhadap kematangan Karier Siswa terbukti secara signifikan baik secara simultan maupun secara parsial (sendiri-sendiri). Kepribadian merupakan faktor penentu bagaimana seseorang akan berperilaku di berbagai situasi. Dalam penelitian ini faktor kepribadian yang berkontribusi secara signifikan adalah neurotism, ciri kepribadian dengan memiliki karakter yang pekerja keras, teratur, tepat waktu, ambisius, teliti, dan terkenal sebagai orang yang terorganisir (Goldberg, 1981). Sedangkan empat faktor lain tidak menunjukkan pengaruh yang signifikan. Rincian kontribusi tertinggi berasal dari Conscientiousness $(B=.185)$ selanjutnya adalah Agreeableness $(B=.017)$, Openness to experience $(B=-$ .019) Neuroticism $(B=-, 022)$, diikuti oleh Extraversion $(B=-, 031)$. Hasil penelitian ini relatif berbeda dengan penelitian sebelumnya yang dilakukan oleh oleh Atli Abdullah, (2017) yang menunjukan bahwa kelima factor menunjukan hasil yang signifikan dengan Kontribusi tertinggi berasal dari Neuroticism $(B=-.158)$, diikuti oleh Extraversion $(B=.148)$, Openness to experience $(B=.109)$, Agreeableness $(B=$. 090), Conscientiousness $(B=.083)$, variabel independen menjelaskan $12 \%$ dari varians dalam kematangan karir.

Faktor kepribadian Conscientiousness ditunjukkan melalui aspek-aspek seperti competence atau kompetensi, dutifulness atau patuh, achievement striving atau pencapain prestasi, order atau keteraturan, deliberation atau pertimbangan, dan self-dicipline atau disiplin. (Stephanie \& Pristinella, 2014).Seseorang dengan tingkat conscientiousness yang tinggi dapat disebut sebagai orang yang terorganisir, pekerja keras, percaya diri, dapat diandalkan, cermat, disiplin, tepat waktu, keras hati, rapi, dan ambisius. Adapun seorang dengan tingkat conscientiuosness yang rendah disebut memiliki ciri sebagai orang yang tidak memiliki motivasi, malas, tidak dapat diandalkan, lemah, acuh, sembrono, dan hedonistis atau suka bersenang-senang. Ciri kepribadian ini dapat mengarahkan pada kematangan karir karena ia mampu menunjukkan upaya untuk mencapai harapan dan keinginannya dalam karir, dengan ciri kepribadian ini, siswa akan dapat menunjukkan kemampuannya untuk melakukan eksplorasi dan berkomitmen terhadap pilihan karirnya

Berkaitan dengan dukungan sosial. Berdasarkan hasil pengujian baik secara simultan maupun terpisah variabel dukungan sosial terbukti berpengaruh secara parsial terhadap kematangan karier siswa. Dukungan sosial yang diterima dari lingkungan sekitar seperti dari orang tua, sahabat, guru, teman sebaya (peer) yang dapat membantu individu dalam menghadapi kesulitan yang sedang dihadapi. Penelitian ini menunjukan semakin tinggi dukungan sosial yang dialami, maka semakin tinggi pula kematangan karier yang dialami siswa. Hasil penelitian ini sejalan dengan penelitian sebelumnya dari Yusanti (Ghanis, 2015) yang menunjukan adanya hubungan positif antara dukungan sosial dan kematangan karier siswa. Ini juga sejalan dalam penelitian Pramanasari Sintya (2019) menunjukan hasil hubungan positif dan signifikan antara dukungan sosial teman sebaya terhadap kematangan karier dengan subjek penelitian sebanyak 92 orang mahasiswa perantau. 
Hasil-hasil penelitian ini sejalan dengan apa yang diungkapkan oleh Levinson (1998) bahwa pengalaman yang terkait dengan lingkungan akan mempengaruhi kematangan karier seseorang. Interaksi individu dengan lingkungan sekitar dapat berupa dukungan sosial yang dapat membantu individu mengatasi masalah yang sedang dihadapi, dukungan sosial yang diterima individu terutama siswa akan menunjukan adanya penghargaan terhadap individu sehingga dapat merasakan adanya rasa nyaman dan aman untuk terus melangkah ke jenjang berikutnya. Myers (Sri, 2011) mengemukakan bahwa terdapat tiga faktor penting yang mendorong seseorang untuk memberikan dukungan yang positif diantaranya; memberikan rasa empati dengan ikut merasakan kesulitan apa yang dirasakan orang lain, pertukaran sosial seperti hubungan timbal balik perilaku sosial antara cinta, informasi, dan pelayanan, dan selanjutnya norma dan nilai sosial yang berguna untuk membimbing seorang individu menjalankan kewajiban dalam kehidupan.

\section{Kesimpulan}

Berdasarkan hasil analisis data dan pembahasan di atas, maka dapat ditarik kesimpulan, bahwa faktor kepribadian neurotism dan dukungan sosial berpengaruh secara signifikan terhadap kematangan karier siswa.

Penelitian ini dilakukan pada responden yang relative terbatas. penelitian lanjutan untuk mengetahui peranan faktor kepribadian bisa dilakukan untuk meneliti kematangan karier pada lebih banyak respondesn siswa SMA atau bahkan ke Perguruan tinggi. Penelitian berikutnya yang ingin meneliti kematangan karier dapat mempertimbangkan untuk penelitian lebih lanjut faktor-faktor lain seperti faktor (internal) orientasi masa depan dan faktor (eksternal) secara lebih khusus misalnya dukungan sosial dari konselor karir di sekolah.

\section{Daftar Pustaka}

Ariati, J., \& Muntamah. (2016). Hubungan antara Kelekatan terhadap Teman Sebaya dengan Kematangan Karir pada Siswa Kelas XI SMK Negeri 1 Trucuk Klaten. Jurnal Empati, 5(4), $705-710$.

Atli, A. (2017). Five-Factor Personality Traits as Predictor of Career Maturity. Eurasian Journal of Educational Research, 68, 151-165. https://doi.org/10.14689/ejer.2017.68.8

Cutrona, C., Russell, D., \& Rose, J. (1986). Social Support and Adaptation to Stress by the Elderly. Psychology and Aging, 1(1), 47-54. https://doi.org/10.1037/0882-7974.1.1.47

Fitria Rahmi, D. P. (2017). Kematangan karir ditinjau dari jenis kelamin dan jenis sekolah di kota $\begin{array}{lllll}\text { Padang. } & \text { Jurnal } & \text { RAP }, & \text { \&(1), }\end{array}$ http://ejournal.unp.ac.id/index.php/psikologi/article/view/7949

Ghanis, Y. (2015). Correlation Between Social Support With Career Maturity On High School Students In Bogor. Skripsi. http://weekly.cnbnews.com/news/article.html?no=124000

Herin, M., \& Sawitri, D. R. (2017). Dukungan Orang Tua Dan Kematangan Karir Pada Siswa Smk Program Keahlian Tata Boga. Jurrnal Empati, 6(1), 301-306.

https://www.bps.go.id/. (n.d.).

Herlina. (2013). Perkembangan Masa Remaja (Usia 11/12 - 18 tahun). Mengatasi Masalah Anak Dan Remaja Melalui Buku. Bandung: Pustaka Cendekia Utama. https://www.bps.go.id/. (n.d.).

Iman, S., Siwabessy, D. L. B., M.Pd, Komalasari, G., \& M.Psi. (2014). Hubungan antara Efikasi Diri Dengan Kematangan Karir Siswa Kelas XI SMKN 8 Jakarta. 31-37.

John, O. P., \& Srivastava, S. (1999). Big Five Inventory (BFI). Journal Film Quarte, 51(4), 65-66. https://doi.org/10.2307/1213263

Juwitaningrum, I. (2013). Program Bimbingan Karir untuk Meningkatkan Kematangan Karir Siswa SMK. PSIKOPEDAGOGIA Jurnal Bimbingan Dan Konseling, 2(2), 132-147. https://doi.org/10.12928/psikopedagogia.v2i2.2580

Levinson, E. M., Ohler, D. L., Caswell, S., \& Kiewra, K. (1998). Six Approaches to the Assessment of Career Maturity. Electronic Journal, 76, 107-114. 
ISSN : $2655-1640$ (Online)

Listyowati, A., Andayani, T. R., \& Karyanta, N. A. (2012). Hubungan Antara Kebutuhan Aktualisasi Diri dan Dukungan Sosial dengan Kematangan Karir pada Siswa Kelas XII SMAN 2 Klaten. Jurnal Wacana Psikologi, 116-145.

Naila, K., Nugraha, K. A., \& Arif, S. T. (n.d.). Hubungan antara Adversity Quotient dan Dukungan Keluarga dengan Kematangan Karir Remaja Yatim di SMA di Surakarta. 14-27.

Ratnaningsih, I. Z., Kustanti, E. R., Prasetyo, A. R., \& Fauziah, N. (2016). Kematangan Karier Siswa Smk Ditinjau Dari Jenis Kelamin Dan Jurusan. Humanitas, 13(2), 112-121.

Pramanasari, S. F. (2019). Pengaruh Dukungan Sosial Teman Sebaya Terhadap Kematangan Karir Mahasiswa Perantau. Jurnal Riset Mahasiswa Bimbingan Dan Konseling, 5(8), 542-555.

Saifuddin, A., Ruhaena, L., \& Pratisti, W. D. (2017). Meningkatkan Kematangan Karier Peserta Didik SMA dengan Pelatihan Reach Your Dreams dan Konseling Karier. Jurnal Psikologi, 44(1), 3949. https://doi.org/10.22146/jpsi.17378

Savickas, M. L. (2001). A Developmental Perspective on Vocational Behaviour: Career Patterns , Salience, and Themes. International Journal for Educational and Vocational Guidance, 1, 4957 .

Savickas, M. L., \& Porfeli, E. J. (2011). Revision of the Career Maturity Inventory: The Adaptability Form. Journal of Career Assessment, 19(4), 355-374. https://doi.org/10.1177/1069072711409342

Sri, M. (2011). Studi Tentang Hubungan Dukungan Sosial, Penyesuaian Sosial Di Lingkungan Sekolah Dan Prestasi Akademik Siswa SMPIT Assyfa Boarding School Subang Jawa Barat. Jurnal Psikologi Undip, 10(2), 103-114. https://doi.org/10.14710/jpu.10.2.103-114

Sugiyono. (2012). Metode Penelitian Kuantitatif Kualitatif dan R\&d.

Super, D. E. (1980). A Life-Span, Life-Space Approach to Career Development. Journal of Vocational Behavior, 16, 282-298. 
